\title{
Lactic acid bacteria during fish fermentation (rusip)
}

\begin{abstract}
Rusip is one of typical lactic acid fish fermented food originating from Bangka Belitung. To develop this product, the data of lactic acid bacteria involved during fermentation is necessary. This research was aimed at preliminary identifying the lactic acid bacteria at selected day of "rusip" fermentation. A number of 29 isolates were chosen to be isolated and identified. The results showed that the lactic acid bacteria involved at day 1-15 were Streptococcus in the beginning and Lactococcus in the middle of fermentation, while Leuconostoc were present along with fermentation.
\end{abstract}

Keywords: rusip, lactic acid bacteria, fermentation, lactococcus, raw materials
Volume 6 Issue 2 - 2018

\author{
Neti Yuliana, Dyah Koesoemawardani, \\ Susilawaty, Yessy Kurniati \\ Program Studi Teknologi Industri Pertanian, Fakultas Pertanian \\ Universitas Lampung, Indonesia
}

Correspondence: Neti Yuliana, Program Studi Teknologi Industri Pertanian, Fakultas Pertanian Universitas Lampung, Jalan Sumantri Brojonegoro nol Gedung Meneng Bandar lampung, Indonesia, Email neti.yuliana@fp.unila.ac.id

Received: February 27, 2018 | Published: March 27, 2018
Abbreviations: LAB, lactic acid bacteria; KB, spherical colonies; KM, widened colonies; KP, long colonies; KBS, large colonies

\section{Introduction}

Rusip is a traditional fermented fish products known from Bangka Belitung, and found in Lampung and West Kalimantan. Types of fish used as raw materials in the manufacture of rusip are generally small fish such as anchovy or bilis fish. Rusip fermentation is usually a spontaneous fermentation process involving lactic acid bacteria (LAB) with palm sugar as a source of carbohydrates. ${ }^{1}$

Genus of lactic acid bacteria involved in a food fermentation may vary depend on region, type of substrate and or fermentation stages. The lactic acid bacteria encountered in the end product of rusip with the addition of salt and roasted rice are Streptococcus and Lactobacillus, whereas in rusip with the addition of salt and brown sugar were Streptococcus and Leuconostoc. ${ }^{2}$ These lactic acid bacteria were found in the final product of rusip originating from manufacturers in Bangka. Meanwhile, Kusmarwati et al. found Pediococcus as bacteriocin producing lactic acid bacteria from commercial rusip in Bangka and West Kalimantan. The lactic acid bacteria profiles, however, that play a role during the fermentation stage are unknown. Thus, this study was aimed at identifying lactic acid bacteria of rusip at different fermentation stages. Data on the types of lactic acid bacteria that play a role during fermentation are needed to develop further product of rusip such as to improve the quality of the preparation of rusip with selected LAB starter.

\section{Materials and methods}

\section{Material}

Anchovy obtained from fish auction place in Lempasing, Salt and palm sugar obtained from Pasar Gintung Bandar Lampung. The chemicals used are aquades, phenolphthalein indicator, $0.1 \%$ peptone, $0.1 \mathrm{~N} \mathrm{NaOH}$, phosphate buffer, MRS De Man, Rogosa and Sharpe (MRS) agar, physiological salts, violet crystals, iodized salts, safranin, 95\% alcohol, and $3 \% \mathrm{H}_{2} \mathrm{O}_{2}$.

\section{Fermentation of Rusip}

Firstly, the anchovy (Stolephorus sp) was washed and drained. Salt was added to the drained anchovy as much as $25 \%(\mathrm{w} / \mathrm{w})$ of the fish weight and was stirred until blended. After that, sugar palm was added as much as $10 \%(\mathrm{w} / \mathrm{w})$ of the fish weight, and was then stirred until blended. These fish were put in a cleaned plastic jar, was closed tightly and incubated at room temperature to allow fermentation process. ${ }^{4}$ The samples were withdrawn at certain period of time according to the research stages (3,5,10 and 15 fermentation days).

\section{Evaluation of lactic acid bacteria (LAB)}

Evaluation of LAB was done by identifying selected colonies. After grouping by shape and size, each isolate was purified on the MRS medium for a recurrent casting method using a $0.1 \%$ peptone diluents solution until a uniform colony was obtained based on the bacterial cell shape and colony color. The uniform colony was then purified over and over until a single colony was obtained for later identification. Identification was performed in two stages, first initial identification consisting of Gram staining, catalase test, spore test, and total lactic acid bacteria count. The next step after initial identification was perform biochemical tests on selected colonies to determine the genus of LAB following the Harrigan ${ }^{5}$ procedure which included the production of $\mathrm{CO}_{2}$ from glucose, the production of ammonia from arginine, and the production of dextran from sucrose and growth at a temperature of $10^{\circ} \mathrm{C} \pm 2$ (Table 1 ).

Table I Biochemical test results of lactic acid bacteria

\begin{tabular}{lllll}
\hline & Lactococcus & Sreptococcus & Pediococcus & Leuconostoc \\
\hline Gram & + & + & + & + \\
Catalase & - & - & - & - \\
Spore & - & - & - & - \\
Shape & Coccus & Coccus & Tetracoccus & Coccus \\
\hline
\end{tabular}


Table continued..

\begin{tabular}{|c|c|c|c|c|}
\hline & Lactococcus & Sreptococcus & Pediococcus & Leuconostoc \\
\hline Growth at $10^{\circ} \mathrm{C}$ & + & - & $\mathrm{D}$ & + \\
\hline Growth at $45^{\circ} \mathrm{C}$ & - & $\mathrm{D}$ & $\mathrm{D}$ & - \\
\hline $\mathrm{CO}_{2}$ production from glucose & - & - & + & + \\
\hline Growth at salt media $(6,5 \%)$ & + & + & $\mathrm{D}$ & $\mathrm{D}$ \\
\hline Production of ammonia from arginine & - & + & - & - \\
\hline Dekstran production from sucorse & - & - & - & + \\
\hline
\end{tabular}

\section{Results}

\section{Isolation of lactic acid bacteria}

During 5 (five) sampling periods (0,3,5,10 and 15 day), there were 29 isolates found. Based on the shape of colonies, these isolates consisted of: spherical colonies (KB), widened colonies (KM), and long colonies (KP), whereas based on colony size, these consisted of: small colonies (KK), medium colonies (KSD) and large colonies (KBS).

Table 2 Biochemical Test

\section{Initial identification}

Preliminary tests showed that all of 29 isolates were Grampositive, coccus with single and chain formation, and did not produce spores. The isolates were negative catalase indicated by the absence of air bubbles after culture testing with $\mathrm{H}_{2} \mathrm{O}_{2}$.

\section{Biochemical test}

The results of testing the biochemical properties to determine the genus of lactic acid bacteria of 29 isolates can be seen in Table 2 and the spread of LAB at each fermentation periode is presented in Table 3 while the determination scheme can be seen in Figure 1.

\begin{tabular}{|c|c|c|c|c|c|c|}
\hline \multicolumn{7}{|c|}{ Testing } \\
\hline No & $\begin{array}{l}\text { Code of } \\
\text { Isolate }\end{array}$ & $\begin{array}{l}\text { Production of } \mathrm{CO}_{2} \\
\text { from Gibson media }\end{array}$ & $\begin{array}{l}\text { Production of } \\
\text { dexstran }\end{array}$ & $\begin{array}{l}\text { Ammonia production } \\
\text { from arginine }\end{array}$ & $\begin{array}{l}\text { Growth at } \\
10^{\circ} \mathrm{C} \pm 2\end{array}$ & $\begin{array}{l}\text { Possibility of } \\
\text { LAB genus. }\end{array}$ \\
\hline I & $K M, 0$ & + & + & + & & Leuconostoc \\
\hline 2 & KBS2 & + & + & + & & Leuconostoc \\
\hline 3 & KSD2 & + & + & + & & Leuconostoc \\
\hline 4 & $\mathrm{KK}_{1} \mathrm{O}$ & + & + & + & & Leuconostoc \\
\hline 5 & $\mathrm{KK}_{1}, 15$ & + & + & + & & Leuconostoc \\
\hline 6 & $\mathrm{KSD}_{2} 15$ & + & + & + & & Leuconostoc \\
\hline 7 & KK3 & + & + & + & & Leuconostoc \\
\hline 8 & KM5 & + & + & + & & Leuconostoc \\
\hline 9 & KMIO & + & + & + & & Leuconostoc \\
\hline 10 & $\mathrm{KSD}_{1}, 15$ & + & + & + & & Leuconostoc \\
\hline 11 & $\mathrm{~KB}_{1} \mathrm{O}$ & - & - & + & & Streptococcus \\
\hline 12 & $\mathrm{KM}_{2} \mathrm{O}$ & - & - & + & & Streptococcus \\
\hline 13 & $\mathrm{~KB}_{3} \mathrm{O}$ & - & - & + & & Streptococcus \\
\hline 14 & $\mathrm{KP}_{2} \mathrm{O}$ & - & - & + & & Streptococcus \\
\hline 15 & $\mathrm{KP}_{3} \mathrm{O}$ & - & - & + & & Streptococcus \\
\hline 16 & $\mathrm{KM}_{3} \mathrm{O}$ & - & - & + & & Streptococcus \\
\hline 17 & $\mathrm{KK}, 3$ & - & - & + & & Streptococcus \\
\hline 18 & $\mathrm{KK}_{2} 3$ & - & - & + & & Streptococcus \\
\hline
\end{tabular}


Table continued.

\begin{tabular}{|c|c|c|c|c|c|c|}
\hline \multicolumn{7}{|c|}{ Testing } \\
\hline No & $\begin{array}{l}\text { Code of } \\
\text { Isolate }\end{array}$ & $\begin{array}{l}\text { Production of } \mathrm{CO}_{2} \\
\text { from Gibson media }\end{array}$ & $\begin{array}{l}\text { Production of } \\
\text { dexstran }\end{array}$ & $\begin{array}{l}\text { Ammonia production } \\
\text { from arginine }\end{array}$ & $\begin{array}{l}\text { Growth at } \\
10^{\circ} \mathrm{C} \pm 2\end{array}$ & $\begin{array}{l}\text { Possibility of } \\
\text { LAB genus. }\end{array}$ \\
\hline 20 & KB5 & - & - & + & & Streptococcus \\
\hline 21 & $\mathrm{KP}_{2} 5$ & - & - & + & & Streptococcus \\
\hline 22 & $\mathrm{KK}_{3} \mathrm{I} 5$ & - & - & + & & Streptococcus \\
\hline 23 & KKO & - & - & - & + & Lactococcus \\
\hline 24 & $\mathrm{KK}_{2} \mathrm{O}$ & - & - & - & + & Lactococcus \\
\hline 25 & KSD5 & - & - & - & + & Lactococcus \\
\hline 26 & $\mathrm{KP}, 5$ & - & - & - & + & Lactococcus \\
\hline 27 & $\mathrm{KSD}, 5$ & - & - & - & + & Lactococcus \\
\hline 28 & $\mathrm{KSD}, 0$ & - & - & - & + & Lactococcus \\
\hline 29 & $\mathrm{KK}_{2} \mathrm{I} 5$ & - & - & - & + & Lactococcus \\
\hline
\end{tabular}

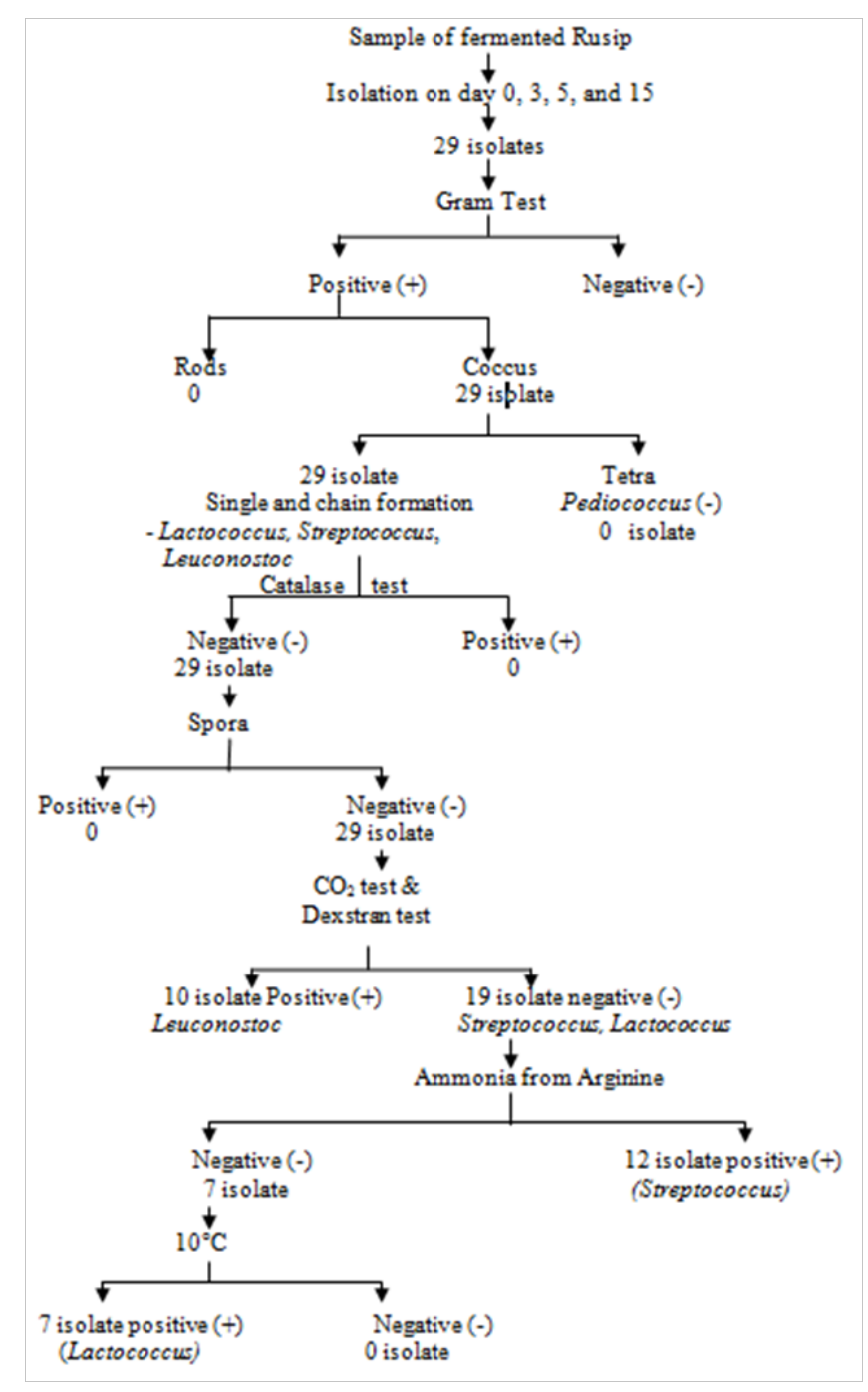

Figure I Identification scheme of lactic acid bacteria on fish fermentation (Rusip). 
Table 3 Total isolates of fermented rusip

\begin{tabular}{lll}
\hline Day of fermentation & Genus of lactic acid bacteria & Total isolates \\
\hline 0 & 6 Isolate of Streptococcus & \\
& I Isolate of Leuconostoc & \\
& 2 Isolate of Lactococcus \\
& 3 Isolate of Streptococcus & 5 \\
& 2 Isolate of Leuconostoc \\
& 2 Isolate of Streptococcus \\
& 2 Isolate of Leuconostoc \\
& 3 Isolate of Lactococcus \\
& 2 Isolate of Leuconostoc & 7 \\
10 & I Isolate of Lactococcus \\
& I Isolate of Streptococcus \\
& 3 Isolate of Leuconostoc \\
I Isolate of Lactococcus & 3 \\
\hline
\end{tabular}

\section{Discussion}

Preliminary tests of 29 isolates showed that all isolates were coccus with single or chain formation, therefore, the biochemical tests were focused to the assessment of the genus with coccus-shaped: Streptoccous, Lactococcus and Leuconostoc except Pediococcus which had morphologically tetrad-shaped.

Testing of $\mathrm{CO}_{2}$ from glucose production on Gibsont Semi Solid media on 29 isolates showed 10 isolates producing $\mathrm{CO}_{2}$ as indicated by the breakup of Gibsont Semi Solid media. Isolates that showed positive results were KM10, KBS2, KSD2, KK10, KK115, KSD215, KK3, KM5, KM10, and KSD115 which could be classified as lactic acid bacteria of Leuconostoc genus. According to Harrigan, ${ }^{5}$ lactic acid bacteria that produce $\mathrm{CO}_{2}$ on Gibson Semi Solid media are only Leuconostoc. In addition, this test showed that Leuconostoc was belonged to hetero fermentative lactic acid bacteria as it produced $\mathrm{CO}_{2}$. The discovery of Leuconostoc on fish fermentation (rusip) at the beginning to the end of fermentation indicated that this bacterium was the dominant bacteria during rusip fermentation. Dessi ${ }^{2}$ also found this bacteria in fermented rusip using brown sugar as a carbon source. The presence of these bacteria in rusip containing $10 \%$ palm sugar is not surprising because Leuconostoc is a lactic acid bacteria that is known as osmofilic bacteria, a group of bacteria that grow on high sugar content ${ }^{6}$. In addition, several studies have shown that Leuconostoc is a genus of lactic acid bacteria that play important role in the fermentation of foodstuffs. Many outhors reported that the Leuconostoc sp is a LAB genus that plays a role in several fermented foods such as fermented pickles (sauerkraut) and idli batter ${ }^{7}$ fermented cassava, ${ }^{8}$ and fermented fruit. ${ }^{9}$ Leuconostoc is also a LAB reportedly present in fermented fish originally from Indonesia. ${ }^{10}$

To confirm that the isolates of KM10, KBS2, KSD2, KK10, KK115, KSD215, KK3, KM5, KM10 and KSD115, were Leuconostoc, the dextran forming test was performed because this test was specific only to Leuconostoc. The positive dextran formation test is characterized by the formation of mucoid colonies on the medium of Sucrose. ${ }^{5}$ The test showed that the isolates of KM10, KBS2, KSD2, KK10, KK115, KSD215, KK3, KM5, KM10, and KSD115 showed positive results, thus it can be ascertained that the isolates were Leuconostoc. Holt et al. ${ }^{11}$ stated that the genus of Leuconostoc are Gram positive, negative catalase, spherical in pairs or chain, not spore, not motile, and anaerobic facultative. Leuconostoc ferment carbohydrates with metabolic results in the form of lactic acid, acetic acid, ethanol, $\mathrm{CO}_{2}$ and mannitol. The growth is rather slow and forms small colonies, and in sucrose-containing media forms mucoid colonies and does not hydrolyze arginine. ${ }^{5}$

Isolates that had negative results on both the $\mathrm{CO}_{2}$ formation test and dextran formation were subjected to the ammonia formation test of the Arginine Broth Streptococci medium. Ammonia production test from Arginine showed that the 12 isolates gave positive result that were KB10, KM20, KB30, KP20, KP30, KM30, KK13, KK23, KSD3, KB5, KP25, KK315. Positive results were demonstrated by the formation of an orange ring after the Nessler Reagent was added to the Arginine Broth Streptococci medium. ${ }^{5}$ This medium is specific only to Streptococcus, so it can be assumed that the isolates of KB10, KM20, KB30, KP20, KP30, KM30, KK13, KK23, KSD3, KB5, KP25, and KK315 were Streptococcus. According to Holt et al., ${ }^{11}$ the lactic acid bacterium of the genus Streptococcus is Gram positive, negative catalase, does not form spores and is anaerobic facultative, can grow at $25-45^{\circ} \mathrm{C}$ but the optimal temperature for its growth is $37^{\circ} \mathrm{C}$. The presence of Streptococcus in fish and fermentation is also reported by Rahayu, ${ }^{10}$ a LAB that dominates on peda, pindang, terasi, and wadi.

Observation of LAB from the fermentation time appeared that Streptococcus dominated in the early days of fermentation (on days 0 and days 3 ) and decreases with fermentation time. At the beginning of Streptococcus fermentation grows rapidly, the growth of these bacteria continues to dominate until mid-stage fermentation. In this study, the $\mathrm{pH}$ of fish in the early days was close to neutral (6 to 7). This $\mathrm{pH}$ value was favourable for the growth of Streptococus. ${ }^{12,13}$ Presence of Streptococcus in the early stages of the fermentation was also reported in plaa-som process, a traditional fermented fish product of Thailand ${ }^{14}$ as well as in "burong bangus, ${ }^{15}$ a fermented fishery product from Philippine,". 
Isolates that showed negative results on the Arginin Broth Streptococci medium (KK0, KK20, KSD5, KP15, KSD15, KSD10 and KK215) were then tested for thier growth on MRS broth at $10^{\circ} \mathrm{C}$. This test to support whether the isolates showed negative results on agar medium, Semi Solid Gibson media and Arginin Broth Streptococci Media. According to Harrigan, ${ }^{5}$ Lactococcus can grow 2 . at $10^{\circ} \mathrm{C}$, so only this test can be used as a reference to determine whether the isolates are Lactococcus or not. Lactococcus lactic acid bacteria are Gram positive, negative catalase, not spores, optimum 3 temperature of $30^{\circ} \mathrm{C}$, can grow at $10^{\circ} \mathrm{C}$, fermenting carbohydrates with lactic acid end products. ${ }^{11}$ The test results show that the possible isolates of KK0, KK20, KSD5, KP15, KSD15, KSD10, and KK215 are Lactococcus. Based on the spread of these bacteria, it appears that Lactococcus was dominant genus in mid-fermented rusip. Presence of this bacteria in rusip was suprising as Lactococcus was not found in 5 . other fermented fish products such as pekasam, peda, pindang, as well as other fermented fish, such as shrimp paste and wadi as reported 6 by Rahayu $^{10}$. This may be due to a unique mixed media medium of rusip fermentation that used palm sugar as a carbon source instead of rice or even without carbohydrate sources addition as in other fish fermentation. In addition, Lactococcus was mostly isolated from cane juice $^{16,}$ dairy products ${ }^{17}$ as well as vegetables and fermented fruits..$^{18,19}$

During fermentation, the lactic acid bacteria use palm sugar as a source of energy with the result of lactic acid. This sugar metabolism results in an increase in total acid and a decrease in $\mathrm{pH}$, thus supporting the growth of lactic acid bacteria that are more acid-resistant such as Lactococcus and Leuconostoc. The $\mathrm{pH}$ profile of fermented rusip showed that $\mathrm{pH}$ change began to occur on the 3rd day of fermentation (pH 6.3) and was highly significant at day 10 of fermentation ( $\mathrm{pH}$ 5.9) and 15 (pH 5.5). This finding is in line with the results reported by previous study. ${ }^{20,21}$ However, The $\mathrm{pH}$ of rusip obtained in this study was higher than previous work reported. ${ }^{22}$

\section{Conclusion}

Isolation of lactic acid bacteria during 15 days rusip fermentation obtained 29 isolates with characteristics of coccus, Gram positive $(+)$, negative catalase (-), and negative spores (-). These 29 isolates of lactic acid bacteria consisted of 10 isolates of Leuconostoc, 12 isolates of Streptococcus, and 7 isolates of Lactococcus. Thus, it can be concluded that the lactic acid bacteria contributing during rusip fermentation (rusip) was Leuconostoc, Streptococcus, and Lactococcus. Based on the fermentation periods, presence of these bacteria was vary. The genus Streptococcus was more common in early fermentation, whereas the genus of Lactococcus was more common in mid-fermentation and at the end of fermentation, the most dominant was Leuconostoc.

\section{Acknowledgements}

The authors acknowledge the personals of the Laboratory at THP (University of Lampung) and Balitvet, Bandar Lampung, for their assistance in this work

\section{Conflict of interest}

The authors declared that no conflict of interest exists.

\section{References}

. Putri DM, Budiharjo A, Kusdiyantini E. Isolasi, Karakterisasi Bakteri Asam Laktat, dan Analisis Proksimat dari Pangan Fermentasi Rusip Ikan Teri (Stolephorus sp.). Jurnal Biologi. 2014;3(2):11-19.

Dessi. Sifat Kimia dan Ciri-Ciri Bakteri Asam Laktat pada Rusip yang Dibuat Dengan Berbagai Sumber Karbon. Indralaya: Universitas Sriwijaya; 1999.

Kusmarwati A, Arief FR, Haryati S. Exploration of Bacteriocin from Lactic Acid Bacteria Origin from Bangkanese and Kalimantanese Rusip. JPB Perikanan. 2014;9(1):29-40

4. Yuliana N. Profil Fermentasi Rusip yang Dibuat dari Ikan Teri (Stolephorus sp). Majalah Ilmu dan Teknologi Pertanian Agritech. 2007;27(1):12-17.

Harrigan WF. Laboratory Methods in Food Microbiology. $3^{\text {rd }}$ ed. London: Academic Press Limited; 1998. p. 333-348.

Frazie WC, Westhoff DC. Food Microbiology. 4th ed. New York: McGraw Hill Book Co; 1988:52-55.

Devi CS, Reddy S, Mohanasrinivasan V. Fermentative Production of Dextran Using Leuconostoc spp. Isolated from Fermented Food Products. Frontiers in Biology. 2014;9(3):244-253.

8. Emmanuel CK, Kalpy-Julien C, Lessoy T, et al. Probiotic profiling of leuconostoc species isolated from a traditional fermented cassava product. African Journal of Microbiology Research. 2017;11(10):408-413.

Abekhti A, Daube G, Kihal M. Isolation and Identification of Dominant Osmophilic Leuconostoc Strains from Traditional Date Product "Btana". International Food Research Journal. 2004;21(4):1297-1304.

10. Rahayu ES. Lactic Acid Bacteria in Fermented Foods of Indonesian Origin. Majalah Ilmu dan Teknologi Pertanian Agritech. 2000;23(2):75-84.

11. Holt JG, Sneath PH, Krieg NR, editors. Bergey's Manual of Systematic Bacteriology. $9^{\text {th }}$ ed. William and Wilkin Baltimore. 1994;527-533.

12. Liu Y, Chu L, Wu F, et al. Influence of $\mathrm{pH}$ on Inhibition of Streptococcus mutans by Streptococcus oligofermentans. European J Oral Science. 2013;122(1):57-61.

13. Beal C, Louvet P, Corrieu G. Influence of Controlled $\mathrm{pH}$ and Temperature on the Growth and Acidification of Pure Cultures of Streptococcus thermophilus 404 and Lactobacillus bulgaricus 398. Applied Microbiology and Biotechnology. 1989;32 (2):148-154.

14. Kopermsub P, Yunchalard S. Identification of Lactic Acid Bacteria associated with the production of plaa-som, a traditional fermented fish product of Thailand. International J Food Microbiology. 2010;38(3):200-204.

15. Olympia M, Ono H, Shinmyo A, et al. Lactic Acid Bacteria in Fermented Fishery Product, "Burong Bangus". Journal of Fermentation and Bioengineering. 1992;73(3):193-197.

16. Cock LS, Stouvenel AR. Lactic Acid production by a Strain of Lactococcus lactis subs lactis Isolated from Sugar Cane Plant. Electronic J Biotechnololgy. 2006;9(1):40-45

17. Perin LM, Nero LA. Antagonistic Lactic Acid Bacteria isolated from goat milk and identification of a novel nisin variant Lactococcus lactis. BMC Microbiology. 2014;(14):36.

18. Kimoto H, Nomura M, Kobayashi M, et al. Identification and Probiotic Characteristic of Lactococcous Strains from Plant Material. JARQ. 2004;38(2):111-117. 
19. Abubakr MAS, Al-Adiwish WM. Isolation and Identification of Lactic 21. Koesoemawardani D, Rizal S, Tauhid M. Microbiological and Chemical Acid Bacteria from Different Fruits with Proteolytic Activity. International Journal of Microbiology and Biotechnology. 2017;2(2):58-64.

20. Susilowati R, Koesoemawardani D, Rizal S. Profil proses fermentasi rusip dengan penambahan gula aren cair. Jurnal Teknologi \& Industri Hasil Pertanian. 2014;19(2):138-147. Changes of Rusip during Fermentation. Agritech. 2013;33(3):265-272.

22. Khairi INBM, Huda N, Abdullah WNW, et al. Protein Quality of Fish Fermented Product: Budu and Rusip. Asia Pacific Journal of Sustainable Agriculture Food and Energy. 2014;2(2):17-22. 